\title{
Aristotle, Kant and Weber - Preliminary Philosophical for Journalism Ethics
}

\author{
By José Manuel Chillón*
}

\begin{abstract}
The approach of the moral dimension of news journalism can be done from the need to establish a discipline with the own identity of the wisdom applied, while, that from the urgency of having a tradition of moral thought to know and to invoke and to refer to it more than ever in these times when journalism is in the hands of professionals and businessmen devoid of moral scruples. Moments, of course, in which the journalistic knowledge is also in the making. So, I think that the ancient and modern philosophers should mention a matter as contemporary as journalism. In this paper, I will try to study the contributions that ethics of responsibility, prudence like professional virtue or some notions of kantian ethics and discoursive ethics can offer to journalistic ethics.
\end{abstract}

\section{Introduction}

It is now common to accept that bioethics, environmental ethics or business ethics are disciplines that are part of the list of applied ethics. They have their own principles, they know the professional practices and they represent the moral progress of a particular society which has to solve complex contemporary problems specifically as far away from the cradle to the Greek philosophy or Kantian modernity, to give an example. It would seem then that applied ethics must take a path beginning from zero due to the asymmetry between the most pressing issues of today and apparently the outdated assumptions and approaches in the history of moral thought. However, a more discerning eye will discover that, although the faces of the problems are so different and unthinkable for the old time philosophers, the key issues on which they pivot are exactly the same as those that address contemporary thinkers: the debate on the suitability of the means in relation to the ends intended; the value of virtue, the issue of non-negotiable priority for human dignity, moral autonomy ... so new and so classic, so as of yesterday and today. It is clear to what extent the consolidation of knowledge about applied ethics depends on establishing these links between the most pressing moral issues of our day and the moral approaches of ethical reflection giants, whose shoulders we must continue to rely on. Links must be continually

\footnotetext{
* Professor of Contemporary Philosophy, University of Valladolid, Department of Philosophy, Spain.
} 
remade in a constant hermeneutical work with the pressing challenges that daily present a rapidly changing society such as ours. Journalistic ethics could be considered as applied ethics if the journalistic practice, hard hit by the technological revolution of nearly unpredictable consequences, is permeable to systematic ethical proposals. Aristotle, Kant and Weber, among others, have something to say about the moral principles that guide human action and when this action is professionally dedicated to the production of information transmitted through the media. Thus, to justify what sense of journalistic ethics is applied, ethics contribute to the task of providing enough intellectual entity to that discipline. We propose two complementary theoretical courses. The first one tries to understand journalistic ethics as ethics of responsibility moving weberian's reflections on the political vocation to occupation, also public, on the media reports. The second, meanwhile, will suggest professional ethics grounded in virtue for the responsible public mission: the wisdom of Aristotle's stamp. Tours will be completed with a tracking Kantian ethic and contributions from the pragmatics of Habermas. It will discuss fundamentals, principles and journalistic theory and practice information. Is this a good way to "philosophize about a real problem" which Popper would say?

\section{The Moral Dimension of Public Action: M. Weber}

Journalism news is a chore. Such endeavor is the result of a personal and professional freedom. Modern societies have wanted journalism to represent the right of freedom of expression. A freedom that supports democracy and that recognizes social and political pluralism as a fundamental value of the legal system. But, as it happens to any exercise of freedom it is not free of responsibility. It seems clear therefore that journalistic ethics should think about the moral foundations of this relationship between professional freedom exercised and the special public responsibility due.

Before addressing this question, I propose to recall the classic distinction given by the Spanish philosopher $X$. Zubiri. We refer to the distinction between moral structure and moral content. He distinguished between the constitutive and moral dimension of human action, to the extent that it is free, and between the post-qualification of such action by moral standards of those who have. Human actions can be moral or inmoral but not unethical. Obviously it is not the journalist's professional activity to decide what to report, what to include, how much space to reserve, what should be omitted or in which direction to investigate ... these are professional actions in which the journalist's freedom comes into play. The satisfaction of the fundamental right of the public to receive truthful information depends on the free exercise, 
professional and moral structurally. Hence this special responsibility for which we asked before. This responsibility is the mission given by democracies to informative journalism. There are a few professions in which any move, any choice or any decision may have political repercussions. These are probably only politics and journalism. So I think that a good way to treat the specificity of journalistic ethics may involve recourse to Max Weber and the conception of the moral dimension of the public policy action proposed: the ethic of responsibility.

Knowing that politics aim to achieve the power, and that after power comes violence, is an ethic regulation of politics possible? This is the key question of Weber in Politics as a Vocation, a text appearing in the conference that the German sociologist pronounced in the Free Association of Students of Munich during the winter of 1919. Weber then proposes a certain conception of politics, a realistic conception that takes into account the real situations in which the politician action unfolds and he thinks from there the possibility of ethics for the public mission. A very different realistic conception of political realism is that of Machiavelli that subordinates ethics to the strategic pursuit of policy objectives. And this proposal of Weber is also far from the moral convictions of the man who decides not to interfere in worldly matters that might sully their hands of someone with impeccable convictions. What relationship does the professional politician, who knows the rugged terrain where politics is played, with the necessary moral guidance for their actions? And this is his central idea: "Any action that is morally oriented has to adjust to two different theories that are irremediably opposed: the ethics of conviction and responsibility." 1 The difference between these two forms of guiding ethical action lies in, at first, the inconsistency that appears to exist between the two, knowing that the man who acts out of conviction ignores the actual consequences that their actions may have, whatever they may be. However, Weber immediately appeals to the experience to realize that, on many occasions, to achieve good ends, we must use means that are less so. What happens is that this moral calculus of means in order to get the end is unbearable, because it is irrational, for whoever acts according to the ethic of conviction.

The immediate imposition of absolute moral principles (such as the ethics of conviction) to the actual conditions of the policy would be the perfect reason to disregard the moral interference in public administration. Precisely, because Weber wants to avoid this separation between ethics and politics and the consequent reduction of morality into the private sphere, he proposes the ethic of responsibility as the place of politics itself: an ethic that does not

1. Max Weber, Politik als Beruf (Politics as a Vocation) (Muenchen: Gesammelte Politische Schriften, 1921), 164. 
despise the principles, an ethic that assumes the consequences of moral action as an essential of its reflection.

A responsible politician is one who treads the harsh reality, that governs power motivated by principles which, necessarily, on penalty of being useless, abandons their absolute bound by the same reality, principles that are not only the beginning of each political action, but in the end, when the politician who is mature, the politician who has vocation says, "I stay here." Because if the politician gave a further step he would be betraying his convictions by force of circumstances.

Political vocation is needed to reconcile personal conviction and public demands. Political vocation is needed to avoid the gap between individual morality and the renunciation of the principles that may impose a harsh reality. Vocation, in short, tries to make all public missions ethically responsible tasks. Could we speak, in this same sense of vocation as a journalist? To what extent can the discourse on the moral dimension of journalism be illustrated from a possible ethics of responsibility?

When we ask for the professional responsibility of communication we are asking for the justification of their activity in social life. ${ }^{2}$ What does it do? What are the expectations of citizens about the media and its professionals? First, we say that the responsibility of journalists is the tribute that the profession owes to society to give the essential role of covering the fundamental right of the public to receive truthful information and the media only makes sense if they contribute to that end that gives them meaning. "Almost never pays attention to the fact that the responsibility of the journalist is very big, usually, a sense of responsibility of an honest journalist is rarely below that of a scientist, rather, it is over, as demonstrated by the war."3

The task of journalism is also a call to responsibility for public action. And in that sense, journalists need to know how to adapt to the values recognized, legislated standards and moral virtues to the obligations and professional demands. Accommodating such disparate areas is difficult. But the finding of this tension and the best option depends on the moral stature of the journalist and the newspaper company itself. Journalism provides a service to society. A service that can never give up the implementation of professional moral convictions to serve some type of opportunism or political business. But, a public service cannot ignore the actual conditions under which it operates daily information, and the professional routines that make the truth that journalism aspires to be informative truths built by journalist. So the

2. Ana Azurmendi, Derecho de la Información: guía jurídica para los profesionales de la comunicación (Right to Information: legal guide for media professionals) (Pamplona: Eunsa, 2001), 139.

3. Max Weber, and Adan Koyacsis, El trabajo intelectual como profesión (Intellectual work as a profession) (Barcelona: Bruguera, 1983), 98. 
responsible journalists must take into account the potential impact and foreseeable consequences of their actions. This is neither more nor less, the responsibility that Weber talks to politics. In fact, as García Avilés ${ }^{4}$ recognizes, the issues of media credibility that arise from the mismatch between journalistic practice and public expectations when they know they are not receiving the public service they deserve. The professional communication has a personal commitment to the truth which, in turn, has a social impact as expressed in the Declaration of International Principles of Professional Ethics of Journalism UNESCO: "Because the journalist's social responsibility, the information is understood as a social and not a single product."

Weber's proposal opens the moral debate between means and ends, between the value of some and the timing of others, including, ultimately, teleologism and deontologism. Both are extreme theoretical perspectives. The first, because it ignores the most basic moral principles and sacrifices them for a single purpose and the second because, even in the end, it only speaks of abstract duties, unworkable in such complicated circumstances such as those involving the journalists. When I refer to teleologism, I am calling the moral position that is able to subvert and subordinate any means in terms of a target. The fundamentally important issue, in my opinion, is to note that the moral evaluation is not dependent on if the target is good (such as the public interest) or pernicious but on if the means used are simple instruments, mere tools without moral value. Günter Wallraff's journalism practice is an example of teleologism as described in detail in his book: Cabeza de Turco. What really turns him into a teleologist is the conviction that the end justifies the use of denunciatory means forbidden for journalists: a false identity, mendacity, deceit to access reserved information. In my opinion, Wallraff's strategy is covered in the fundamental belief that has led journalism to be understood as the "watchdog" of good and public interest. It is crucial for the public to know the truth, that instruments, mechanisms and strategies employed, whatever they are, are redeemed by the common good. ${ }^{5}$ At least this is the mentorss'

4. Juan Antonio García Avilés, "Autorregulación profesional y estándares en el periodismo audiovisual" ("Professional Self-Regulation and Standards in Broadcast Journalism") in, De la ética desprotegida: ensayos sobre deontología de la comunicación (Unprotected ethics: essays on ethics of communication), ed. Mónica Codina (Pamplona: Eunsa, 2001), 73.

5. The Wilkins-Coleman study is very instructive in this regard [See, Lee Wilkins, and Renita Coleman, The Moral Media (London: Lawrence Erlbaum Associates, 2005), 93]. After cataloging numerous occasions in which he has won the argument teleologist in newspapers, the paper includes a survey of professionals with the following question: Is the use of the following practices justified when it comes to writing an interesting story or is it vital to the public interest? These practices, sixteen in total, could be described as unjustified or justified under any circumstances. The same journalists called them deceptive journalistic practices. Certainly the online 
thesis of the so-called "Social responsibility theory", a theory that emphasizes freedom of expression and introduces two notions that cannot be ignored: the "public good" and the responsibility of the press that should educate the public exerting as a watchdog on government. Ian Richards, scholar and critic of this theory, warns that there is some exaggeration in these statements. For example, it is true that society has the right to know the Government business, but there are no governments obliged to report it? How can you determine what activities are justified in the public interest when in plural societies such as Australia, there are many public and therefore safe, many possible public goods? $?^{6,7}$

To access with false identity into a source of information, seize confidential documents or wiretaps involved, regardless of the ends that are sought, involves deception, theft, or violates privacy. To guarantee a right cannot be at the expense of infringing other rights. Fundamental ethical principles and moral conscience require to carefully suspend, for now, these lines of research. And forget them? Experience, as recognized by the journalists themselves, warns that the use of such procedures is increasing rapidly as more are interested in the exclusive photo for the cover, in short, it brings into question the notion of public service and informative accountability. Prudence, as a moral and professional virtue, recommends the investigation without haste, the professional cunning without reprehensible tricks. The prudent journalist would then have to seek truthful evidence that does not sacrifice the truth for wanting to quickly find the truth. Journalism ethics, as ethics of responsibility, know that journalism can get the truth otherwise, but this requires longer, more reflective capacity and a caution that in some cases imposes moratoriums to certain lines of research. The lie cannot be justified, even for the public good. ${ }^{8}$ "Trust in some degree of veracity -

survey was conducted in 2002 to journalists associated with IRE (Investigative Reporters and Editors). These deceptive practices ranging from claiming to be someone else, altering quotes, altering photographs, making even untrue statements to the readers/viewers, to others as curious as getting employed in a firm or organization to get inside information. Judging by the responses of journalists, Wallraff strategies would be ethically reprehensible.

6. Ian Richards, Quagmires and quandaries. Exploring journalism ethics (Australia: UNSW Press, 2005), 8.

7. Ibid., "Why should the media watch the governors rather than the governed? From what should the media be 'free', and what should they be 'free' to do? Whose duty is it to ensure that the media carry out any responsibilities they might have? And, to whom are individual journalists responsible - their publics, their news sources, their editors, their proprietors, or, perhaps, themselves?."

8. Sissela Bok, Lying: moral choice in the public and private life (New York: Random House, 1989), 174. 
explained near the beginning of this work - is the fundation of relations among humans; when this trust shatters or wears away, institutions collapse."9

However, teleologism seems to invoke journalistic strategies as common as programming content under the decisions of the hearing which subordinate, supremely, media products to a kind of test of profitability: if the quota share is enough, the revenue will be higher. The program is profitable, but not worth it. And in this case, programmers, knowing the moral gravity of maintaining certain types of programs and certain types of content on the grills, justify their decisions because they are not more than the satisfaction of the interests of a varied audience that has different values and different moral beliefs to be respected. And that presents as democratic a strategy with the view of greater benefit, the market logic.

And so, we see how demagogic speeches try to assimilate ${ }^{10}$ two fields as diverse as democracy and television. A certain conception of democracy, simplistic and self-interested, leads them to make decisions with regard to the opinion polls, starting with a seemingly democratic thesis: all choices are equivalent. So that, to force a conception or "introduce qualitative criteria for discrimination between public preferences, it seems undemocratic and elitist."11

Mediocracy (Council of Europe) pollscracy (concept proposed by Sartori) or audience democracy (concept proposed by Bernard Manin in his study of the evolution of forms of representation in exercising democracy) are some of the concepts commonly used. What do these terms reflect? Neither more nor less than the exchange between the forms of political and media strategies to get audience. Not surprisingly, the term information society is defined precisely by what Habermas called fluidization of politics, that is, the understanding of political activity as determined by the condensation and acceleration of the flow of communication, the information economy and the technological revolution. ${ }^{12}$ However, I think that after these statements, there are two questionable assumptions: first, audiences are active and reflective in order for the election of their preferences. Second, only in this way the notion of autonomy, that liberates the viewer from the undemocratic elitism, triumphs. But then, here is the danger, since most reflected in the ratings and opinion polls are the standard to follow, are an expression of public interest, the qualitative moral criteria would shamelessly be displaced by quantitative, ie, business profits and again, to the fore, the utilitarian teleologism. The

9. Ibid., 31.

10. Hugo Aznar Gómez, "Naturaleza de la comunicación audiovisual: 'Todo por la audiencia'" ("Nature of audiovisual communication: 'All for the hearing'"), in Ética de la comunicación y de la información (Ethics of communication and information), ed. J.A. Agejas, and F.J. Serrano Oceja (Barcelona: Ariel, 2002).

11. Ibid., 73.

12. Jürgen Habermas, Ay Europa! (Is Europe!) (Madrid: Trotta, 2009), 152. 
famous phrase, "the audience has decided that" appears as one of the most conspicuous expressions of the freedom of public media. Are the audiences those who choose or are the media the ones that give the public what they have to choose?

We must reject the moral justification of teleologism for their lack of moral scruples since ethics of responsibility definitely cannot ignore teleologism. It should go around some limits to achieve a greater good and to do everything possible to uncover corrupt frames or irregularities in public administration, for example. Recognize that these goals that motivate and justify the journalist's professional activity are part of a sensible conception of journalistic work. But, what are the moral conviction values to the journalist? Can they be quarantined at any opportunity? It may be time to criticize the Weber classification which considers the ethic of conviction as an absolute moral. This ethic does not consist of such absolute principles that cannot be lived, then, in this way, not only it would not be worth to understand and regulate the weary and worldly political action but also the most sublime mystical action. Yet, there is something to what Weber has been already: political decisions, per se, have public consequences, many of them unpredictable, under which he must act. The key is that the moral character of the public servant has limits. And its moral dimension depends on the recognition of these limits. This is the value of the convictions. It is the "here I stand" which pronounces the responsible politician. Well, the public service that journalism provides to society occurs when the journalist also suspends information, research or ignores a leak because their convictions cannot stretch anymore, because the moral principles do not give a support step further in adapting to circumstances. It is, again, "here I stand".

To my knowledge, the ethics of responsibility of Max Weber is one of the most intellectually consistent proposed of disallowance of opportunistic teleologism and of update of deontologism. A kind of middle ground responsibility ultimately measured by the political vocation, one who has made his professional dedication a way of life. And this, I believe, is the most unique contribution of Weber to a contemporary ethical debate: find that the burden of proof of professional ethics lies in the specific action of the professional, in the way guided by moral principles, in their style of living the virtues and being in the circumstances. The genius and creativity that always accompany moral life depend on this three-way balance

\section{Prudence as a Virtue: Aristotelian Lessons}

How do ethics converge with the moral experience of the person? Or else, is there a personal virtue that can be considered as a professional virtue? Can we talk about something like journalistic virtue? Is it possible to refer to the 
good life of journalism? In principle, it seems that we can establish a fruitful relationship between personal morality (such as experience of the virtues that lead man to the good life) and the responsibility of each specific action to the extent of their public profile.

But let's slow down and let's go to the origins of the problem of the first moral philosophy: How does one acquire virtue? Can we teach people to be virtuous? Sure we can, answers Plato, to the extent that we connect the essential relationship that the Sophists are determined to discredit: the one between virtue and knowledge. To teach virtue is encouraging to learn, and learning depends not on "the introduction of sight to the eyes, but to guide the eye $e^{\prime 13}$. And all this because only by knowing the good, just doing the progressus of knowledge, can put into practice what has been known and may be the regressus of politics.

Virtue is learned, Aristotle recognizes this. How? Being virtuous, that is, performing certain actions that, by habit, end up being part of our way of being. "There are thus, by nature nor contrary to nature the virtues implanted in us. Rather we are adapted by nature to acquire them, but that is mature in us the habit."14 And, to be virtuous is to be authentic and fully realized. Virtue has to do with what should be, what better way to discover what we are, what our essence is, than to know consistently what to do. Moral behavior requires knowledge, deliberation of means and freedom of choice of these. We are not talking in vain about practical behavior. ${ }^{15}$

In this sense, Aristotle's ethics can be described as the ethics of happiness, understood as the ultimate fulfillment of what man should be, that is, as the fullness of rationality. But happiness is not only reserved to the mysticism of the wise student of theoretical science. More here, in the practical dimension of human life and particularly in politics, it is possible to find happiness this time understood as "good life". Ethics has no meaning in itself, unless it is oriented toward political life, therefore, the individual is in potency to the community that is an act. True citizenship depends on this relationship between the individual and the community. The polis is a school of virtue and, thus, being a good person happens for being a good citizen. There can be a chasm separating the individual excellence of civic engagement, therefore, of public engagement. So, prudence is the virtue of journalism, the kind of hinge between wisdom and action, between theory and praxis, between moral convictions and adaptation to the most adverse circumstances. Let it go to the sources for a moment.

13. Plato, Republic, trans. G.M.A. Grude, revis. C.D.C. Reeve (2nd Ed.) (Indiana: Hackett Publishing Company, 1992), 517d.

14. Aristotle, Nichomachean Ethics, trans. David Ross, edit. Lesley Brown (Oxford: Oxford University Press, 2009), 1103 23-26.

15. Ibid., 1114b 25ss. 
Aristotle defines prudence as a "provision that allows a man to reason well about what is good and convenient for himself"16 and so, the man is prudent "not in a particular sense, such as health and vigor of body, but about things that should contribute generally to virtue and happiness." As a disposition, as he said later, rational, real and practical ${ }^{17}$ does not seem to enter the field of theoretical episteme but rather on the side of practical knowledge. Prudence is an intellectual virtue (dianoetic) formed by the rationality of ends and the truth, in this case the practical truth: the truth with respect to the real live man, different from the truth to which mathematics or physics aspire.

Prudence is the virtue of the particular man who has to deal with not entirely safe decisions, with not entirely valid means and with not entirely clear purposes. Prudence is the moral tool that accompanies man at the risk inherent in any free action and it is the virtue that guides man to the uncertainty of life in which he has to act. Man seeks happiness as the ultimate goal in each of their actions. This happiness is a moral lifestyle that cannot be disconnected from the essential lifestyle proper to it: rationality. Therefore, the exercise of reason and human life lived in true demand in the development of practical arrangements with targeted ingredients such as: instruction or knowledge, memory of past experience, circumspection and therefore the analysis of the specific circumstances and the balancing of the risks involved and, finally, the application of the general law or universal to the particular case. The prudent man, being a calculating man who values all decisions based on their connection with the ultimate goal, determined by him in terms of cost-benefit analysis, does not operate with an instrumental skill. That is not prudence. "Therefore, good deliberation consists of righteousness according to what is desirable for the purpose apprehended for true understanding." 18 Prudence is a rational exercise, not of strategic rationality, but of practical rationality, that guides the life of a particular man to happiness. "Prudence-Aristotle insists- is intended on the human and on what can be deliberate, in fact, we argue that the prudent operation is to deliberate well, and no one deliberates about what can't be otherwise, or to what has no end, and this is the practical good."19 The prudent man knows not only the universal, but also the particular: the context in which human activity takes place. And then, the prudent man is he who chooses the middle ground ${ }^{20}$ in which there is virtue. The middle ground is measured by the man who has lived and chosen wisely, who has consistently proven to be responsible. The prudent man is, in short, someone who knows how to exercise judgment in individual cases. Therefore, it seems clear that prudence
16. Ibid., 1140a 25.
17. Ibid., $1140 \mathrm{~b} 4 \mathrm{ss}$.
18. Ibid., 1142b 30ss.
19. Ibid., $1141 \mathrm{~b} 3$ y ss.
20. Ibid., 1106b 36 . 
requires a skill, a skill not to be confused with the prudence, "although prudence can't exist without it."21

So, we recognize that prudence can be the most important journalistic virtue. Without prudence, professional attitudes like truthfulness, accuracy and honesty, would become advertising ideals of journalistic work and theoretical recommendations of no practical value, an instruction manual which may be abandoned when the circumstances are imposed. Prudence makes these personal attitudes become genuine moral virtues.

The professional has to know what these attitudes are (accuracy, precision, honesty) and learn how to exercise them. Well, this training, this habit is the prerequisite for setting the moral character of the truthful, accurate and honest journalist. The constellation of circumstances requires the professional journalist to consider professional attitudes but without forgetting the real contexts in which the news is born. Only prudence can guide practical reasoning of journalists about what to do in each circumstance. And, a prudent man of Aristotle as Aubenque remembers, brings qualities like good sense and uniqueness, natural and good experience, the theoretical sense and practical ability, fairness, efficiency, accuracy, cautious lucidity, heroism, inspiration and work. The prudent human being is, "neither a 'beautiful soul' nor Machiavelli; He is inextricably the man of inside and outside, of the theory and practice, of the end and means, of the awareness and action."22

Aristotle did not speak in vain. We cannot reduce every professional attitude to prudence. If so, we would be proposing overly subjectivist ethics, with the consequent danger of insisting on an unbearable middle ground for every moral conscience to grant, for example, the same space and time for the victims to the executioners. Prudence without moral virtue would become no more than a strategy, a ploy likely to justify any end. So what the author finds most compelling is to take an Aristotelian lesson: no virtue, no professional attitude can be exercised without prudence, without virtue that requires that the value gets out of abstract ideas and is carried out in specific circumstances. And so, codes of ethic or standards of conduct deplete the wealth of a motley circumstantially and incomprehensible reality. In the end, the law, the spirit of the law, must be implemented. Any model? Yes, the prudent journalist. He who has made his profession a service to others and precisely in this endeavor, has become more virtuous, most excellent. However, no rule, no book, no model of life frees man from having to gamble on the field, from having to choose.

And this freedom is what sustains the responsibility to guide their professional actions. This is the key connection between the ethics of journalistic responsibility and professional virtue understood in terms of

21. Ibid., 1144a 28.

22. Pierre Aubenque, La prudence chez Aristotle (Caution Aristotle) (Paris: Press Universitaires de France, 1999), 138. 
prudence between Aristotle and Weber and that is the good life of the journalist: in knowing how to offer the community the information it needs to be politically active. The link between prudence and responsibility consists in not giving up convictions, assuming the truth of them lies in their ability to be implemented. So, the journalist who has a vocation is precisely the prudent and responsible professional.

\section{From Kant to Habermas}

The illustrated practical reason meets the "majority" when it breaks its metaphysical or religious links, when he leaves forever the easements that do not allow it to be autonomous. ${ }^{23}$ Moral and free conscience, which are selfimposed rules issued by their own reason, is the sacred tabernacle. So Kant exposes it: "It was found that the idea of freedom was inseparably linked to the concept of autonomy, and with it the universal principle of morality that underlies the idea of all actions of rational human beings." 24 But the autonomy of reason and moral law that requires the same reason is not governed by particularistic principles seeking individual interests but principles that have only moral value that is universal and unconditioned: these principles should be respected by everyone and always. Duties, therefore, are not subordinated to the results. Thus it is possible to act out of duty and while doing so to respect the dignity of the moral subject, a true universal legislator. The categorical imperative, the fundamental law of pure practical reason, ${ }^{25}$ is the ultimate expression of duty which is not subordinated to benefits, which is not subordinated to ends. It is an imperative which is not able to be strategically used or manipulated.

There is no doubt that this conception of moral autonomy has features appreciated by contemporary moral consciousness, as can be seen in the Universal Declaration of Human Rights, therefore, achievements that have shaped the moral conscience of society. The dignity of the human person can be the moral imperative for journalism too. The categorical imperative of journalism news is understood as a term about which there are no room privileges or negotiations. This imperative is an unconditional and universalizable cornerstone of journalistic ethics, and its respect, that is, the representation of the law itself, a symptom, the best sign of the moral stature of professional information.

23. Inmanuel Kant, "An answer to the Question: What is Enlightenment" in What is Enlightenment? (California: University of California Press, 1996), 58.

24. Inmanuel Kant, Fundamentación de la metafísica de las costumbres (Groundwork for the Metaphysics of moral) (Barcelona: Espasa-Calpe, 1973), 121.

25. Ibid., 57. 
In the words of Kant: "Rational beings are persons because their nature distinguishes them as ends in themselves, that is, as something that cannot be used merely as means and, therefore, limited in that sense every whim." 26 If the media enforces respect for human dignity, if the impassable limit of their professional actions is marked by respect for commonly shared moral standards and expressed in human rights, it will help foster the sense of illustration. And this is the key: the formation of a moral philosophy of journalism, in Kantian terms, it is the expression of an informative task that is committed primarily with the freedom of man. And, the ability of reason to determine the will and to become this way in practical reason, aims to analyze the present in which freedom has to deal with time. And this is the permanent legacy of the Enlightenment: analyze the present with critical capacity. But isn't the present essentially a temporal dimension of media? Isn't the present the time dimension built properly by the journalism news? Well, here is the contribution of the Kantian moral proposal to the journalistic ethics: that any information has as a principle, moral and professional imperative. An imperative that has the following formulation: act in such a way that your professional informative action, promotes respect for the man and his dignity.

The kantian principle of universalization (principles valid for everyone and forever), according to Habermas, seems indisputable but not in the form of an individual imperative. It is human reason that is constitutively dialogical. Here is the essential thesis of discoursive ethics. We have to remember that these ethical theories are based not on moral consciousness, the capacity of human reason to make moral judgments, but in the language. That is, based on the ability of people to understand and to reach agreements. Thus, it is understood that language is the human faculty that makes us move from the individual person to the intersubjective one.

The speaker implicitly recognizes the ability of the listener to utter words, to understand and to reach agreements. What are the rational budgets of the communicative actions, as Habermas calls them? One of these budgets is the correction of the standards, so that, every rule can be discussed. This means that their validity claims, as a rule, can become argued. If the argument about the truth claims of propositions is called the theoretical discourse, in this case, as we are concerned about the correctness of moral standards, we mean a practical discourse. A discurse that occurs when there are communication conditions as the following: to maintain a minimal logic in the argument, that the speaker states only what he believes, that every subject capable of speech and action can participate and may problematize any assertion. It seems clear that the legitimacy of the rules, in pluralistic societies such as ours, cannot be achieved regardless of the inclusive dialogue of all those involved in discursive conditions. In short, there is no prior and independient principles

26. Ibid., 83. 
of intersubjetive dialogue. Communicative rationality discovers that the telos of language is understanding the agreement. From Aristotle, we know that to utter words is an eminently rational activity only if these words are understood, only if the society that surrounds the speaker knows what this means. Could it be the language and its intrinsic search for agreements, the best sign to know that the Enlightenment freedom project is still an unfinished project? And the media, born to serve freedom, does not meet the guidelines for the creation of professional ethics in their ability to colonize the world of life and, therefore, in his decisive contribution to enlightened the progress and emancipation of man?

The proximity of the proposed discursive and the deliberative democracy is guaranteed by a free public opinion and a mature and responsible public opinion. So, also the moral dimension of journalism has its obvious political implications, and therefore, good journalistic practice depends on accelerating the construction of the deliberative public space where citizens not only have the information needed to participate in the system available, but they find in media, authentic channels for participation in public affairs. But beware because the media can also influence the opposite direction. In knowledge societies like ours, the close link between information and overwhelming power and influence of the media makes these have an authoritarian face almost inseparable from its emancipatory potential, ${ }^{27}$ a dual nature that greatly affects the moral discourse on media. The author has insisted that, the authenticity of the democratic system depends on good journalistic practice, according to the discursive ethics. But what determines that good practice? What conditions must be met for the rules governing the professional informative task pass the discursive test?

First, it would be necessary to consider all those affected by them and to not accept them as correct but as the rule that everyone could accept. Whereupon, the debate over whether the state should regulate the media or whether the media should regulate themselves, discursively, seems solved: neither an external regulation can be exercised without violating freedom of expression guaranteed by the democracies, neither current drift media advices only self-regulatory rules without any public control. Journalists, media companies, the state and the public may be considered as those affected by the rules governing the profession. Then, how can we take them into account? Promoting meetings so that, informative decisions can daily take account of the responsibility of all members of the wording and encouraging entrepreneurship to get the accounting departments to subordinate their legitimate benefits to the public journalism's service. Providing platforms for that, different stakeholder groups can be expressed by allocating space for

27. Jürgen Habermas, The theory of communicative action II. A critique of functionalist reason (Boston: Beacon Press, 1987), 553-554. 
citizens. Space where citizens can problematize any assertion that has made the media or those that affect it, devoting specific sections for the public to express their positions, wants and needs or promoting consumer information institutions that collect public sensitivity to certain programming or even to a journalistic investigation, to morally controversial procedures or to newspaper reports on special topics such as draft tragedies, domestic violence, immigration ... and why not, creating a state board that oversees the process of media and takes punitive force, an independent council of ideological swings of political parties. Although with no doubt, the best demonstration of rejection is none other than the moral condemnation, which is punishable by zero shares or by a little sale of copies. Requirements, all of them, with that journalism can justify the validity claims of ethical norms pursued, being both the channel and means for active citizenship and real democracy.

However, a discoursive ethic is valid as an ethic of procedure, that is, a kind of moral mechanism to analyze if the rules issued by the professional practice are legitimate or not. But an ethic is not reducible to a rule, to a codified law, to a code of ethics. Neither of the broadest statutes of wording can accommodate the multiplicity of situations, dilemmas or problems that are part of the land of the journalist, of the professional circumstances.

Society not only asks the media to limit their potential to threaten about rights at the expense of protecting other rights, but society also requires that the media promotes such values as freedom, tolerance, pluralism, respect for children, the condemnation of terror and violence, maximums that are not guaranteed by the regulatory minimum but by the professional excellence. Therefore, training future professionals in virtue seems like a good way to make the media servers of those great moral ideals to which ethical reflection should never give up.

\section{Conclusion}

The correct expression and the right word, the selection and management of the information or images and photographs, an extensive documentation as possible, the appearance of all voices without detracting in any ... all these and many more are professional routines which undoubtedly have a moral dimension. And so, journalistic ethics, indirectly, and codes of ethics founded on it directly, propose rules that affect speech and expression, in editing and in documentation, in writing and in speech and therefore in any task. An ethic is not an occasional condition but must always accompany journalism as "the buzz to a hornet" in the felicitous expression of García Márquez. ${ }^{28}$

28. So much critical take this into account which, according to Ian Richards (2005) in the Introduction to his book, the first condition to build journalism ethics is that 


\section{Bibliography}

Aristotle. Nichomachean Ethics. Translated by David Ross, and edited by Lesley Brown. Oxford: Oxford University Press, 2009.

Aubenque, Pierre. La prudence chez Aristotle (Caution Aristotle). Paris: Press Universitaires de France, 1999.

Aznar Gómez, Hugo. "Naturaleza de la comunicación audiovisual: 'Todo por la audiencia"' (Nature of audiovisual communication: 'All for the hearing'). In Ética de la comunicación y de la información (Ethics of communication and information), edited by J.A. Agejas, and F.J. Serrano Oceja, 55-74. Barcelona: Ariel, 2002.

Azurmendi Ana. Derecho de la Información: guía jurídica para los profesionales de la comunicación (Right to Information: legal guide for media professionals). Pamplona: Eunsa, 2001.

Bok Sissela. Lying: moral choice in the public and private life. New York: Random House, 1989.

García Avilés, Juan Antonio. "Autorregulación profesional y estándares en el periodismo audiovisual" ("Professional Self-Regulation and Standards in Broadcast Journalism"). In De la ética desprotegida: ensayos sobre deontología de la comunicación (Unprotected ethics: essays on ethics of communication), edited by Mónica Codina. Pamplona: Eunsa, 2001.

Habermas, Jürgen. The theory of communicative action II. A critique of functionalist reason. Boston: Beacon Press, 1987.

Habermas, Jürgen. Ay Europa! (Is Europe!). Madrid: Trotta, 2009.

Kant Inmanuel. Fundamentación de la metafísica de las costumbres (Groundwork for the Metaphysics of moral). Barcelona: Espasa-Calpe, 1973.

Kant, Inmanuel. "An answer to the Question: What is Enlightenment." In What is Enlightenment?. California: University of California Press, 1996.

Plato. Republic. Translated by G.M.A. Grude, and Revised by C.D.C. Reeve (2 ${ }^{\text {nd }}$ Ed.). Indiana: Hackett Publishing Company, 1992.

Richards, Ian. Quagmires and quandaries. Exploring journalism ethics. Australia: UNSW Press, 2005.

Weber, Max. Politik als Beruf (Politics as a Vocation). Muenchen: Gesammelte Politische Schriften, 1921.

Weber, Max, and Koyacsis, Adan. El trabajo intelectual como profesión (Intellectual work as a profession). Barcelona: Bruguera, 1983.

Wilkins, Lee, and Renita Coleman. The Moral Media. London: Lawrence Erlbaum Associates, 2005.

professionals understand that, "each and every one of their profesional decisions have an ethical dimension" from, "who to interview and who not to interview; who to quote and who not to quote; which angels to emphasise and which to play down" to, "decisions about how the information will be presented, and to whom." 